\title{
Households and families
}

Jen Beaumont

Edition No: Social Trends 41

Editor: Jen Beaumont

Office for National Statistics

\section{Social Trends 41}


ISSN 2040-1620

\section{A National Statistics publication}

National Statistics are produced to high professional standards set out in the Code of Practice for Official Statistics. They are produced free from political influence.

Not all of the statistics contained in this publication are National Statistics because it is a compilation from various data sources.

\section{About us}

\section{The Office for National Statistics}

The Office for National Statistics (ONS) is the executive office of the UK Statistics Authority, a non-ministerial department which reports directly to Parliament. ONS is the UK government's single largest statistical producer. It compiles information about the UK's society and economy, and provides the evidence-base for policy and decision-making, the allocation of resources, and public accountability. The DirectorGeneral of ONS reports directly to the National Statistician who is the Authority's Chief Executive and the Head of the Government Statistical Service.

\section{The Government Statistical Service}

The Government Statistical Service (GSS) is a network of professional statisticians and their staff operating both within the Office for National Statistics and across more than 30 other government departments and agencies.

\section{Contacts}

\section{This publication}

For information about the content of this publication, contact Jen Beaumont

Tel: 01633651622

Email: social.trends@ons.gsi.gov.uk

\section{Other customer enquiries}

ONS Customer Contact Centre

Tel: 08456013034

International: +44(0)8456013034

Minicom: 01633815044

Email: info@statistics.gsi.gov.uk

Fax: 01633652747

Post: Room 1.101, Government Buildings,

Cardiff Road, Newport, South Wales NP10 8XG

www.ons.gov.uk

\section{Media enquiries}

Tel: 08456041858

Email: press.office@ons.gsi.gov.uk

\section{Copyright and reproduction}

(C) Crown copyright 2011

You may re-use this information (not including logos) free of charge in any format or medium, under the terms of the Open Government Licence.

To view this licence, go to: www.nationalarchives.gov.uk/doc/open-governmentlicence/

or write to the Information Policy Team, The National Archives, Kew, London TW9 4DU

email: psi@nationalarchives.gsi.gov.uk

Any enquiries regarding this publication should be sent to: info@statistics.gsi.gov.uk

This publication is available for download at: www.ons.gov.uk 
People live in different types of households and families during their lifetime. Most begin life in the parental home and later they may set up home alone, with other non-related adults or by starting a family. Families are started when people form partnerships or marry, or when they have children. Understanding the distribution of the population by household and family type is important for many different organisations in the public and private sectors, including policy makers dealing with issues such as health, housing and benefits. Issues such as unemployment and poverty can often be better understood by looking at the characteristics of households and families. Information about households and families also shows how society is changing. This chapter provides the latest data on the number and composition of households and families in the UK and looks at trends over time.

\section{Key Points}

\section{Household composition}

- There were 25.3 million households in Great Britain in 2010, an increase of 9.0 million since 1961 and 1.4 million since 2001

- Average household size has decreased from 3.1 persons in 1961 to 2.4 persons in 2010

- A smaller proportion of households in Great Britain have children living in them in 2010 than in 1961 , and those households with children have fewer children living in them

\section{People living in households}

- The number of people living in households in the UK has increased by 3.1 million from 58.3 million in 2001 to 61.4 million in 2010

- The number of people living alone increased from 7.0 million to 7.5 million between 2001 and 2010

- The proportions of all people living alone in specific age groups increases with age; in 2010 about three per cent of those age 16 to 24 lived alone compared to over 45 per cent of those aged 75 and over

\section{Families}

- In 2010 there were an estimated 17.9 million families, an increase from 17.0 million in 2001 with an increase of 0.6 million cohabiting couple families and 0.4 million lone parent families offset by a decrease of 0.1 million in the number of married couple families

- There were an estimated 50.8 million people living in families in 2010 , an increase from 48.8 million in 2001

- The most common type of family in the UK in 2010 consisted of a married couple with or without children, although there had been a decrease from an estimated 72.4 per cent of all families in 2001 to 68.0 per cent in 2010

- Families consisting of a cohabiting couple with or without children increased from 12.5 per cent of all families in 2001 to 15.3 per cent 2010 , and lone parent families increased from 14.8 per cent in 2001 to 16.2 per cent in 2010 
- In 2010 there were an estimated 7.7 million families with dependent children and 13.3 million dependent children living in those families

- The most common type of family in the UK at the time of the survey in 2010 contained one child (46.3 per cent of all families in 2010)

\section{Family formation}

- Around two thirds of marriages (67 per cent) in 2009 in England and Wales were by civil ceremony, a similar proportion to 2008 but a considerable increase compared with 1981 when only 49 per cent of marriages were by civil ceremony

- In 2009 in the UK nearly 6,300 civil partnerships were registered, a decrease of nearly 900 compared to 2008

\section{Divorces and dissolution}

- There has been a consistent downward trend in divorces in England and Wales between 2003 and 2009: the decrease between 2008 and 2009 was about 6.4 per cent (from 121,700 to 113,900)

- Between 1989 and 2009 the total number of children of divorcing couples of all ages decreased from just over 216,000 to nearly 154,000 ; this is partly because of the overall decrease in the number of divorces and partly because the average number of children involved in each divorce had reduced

\section{Births}

- In 2009 there were 706,200 live births registered in England and Wales, compared with 783,200 in 1971 and 708,700 in 2008

- The age distribution of women giving birth in England and Wales has changed considerably: in 1971 nearly four out of five births were to women aged less than 30, by 2009 only just over half were to women of this age

- In 197145.5 per cent of births outside marriage in England and Wales were joint registrations, by 2009 this had increased to 86.6 per cent and nearly two thirds (65.7 per cent) of all registrations outside marriage were from parents living at the same address

\section{Conceptions and abortions}

- Provisional estimates for 2009 suggest that the number of conceptions in England and Wales had increased by 0.9 per cent since 2008

- Between 1991 and 2009 the number of conceptions to women younger than 30 decreased markedly while the number to women aged 30 and over increased

- The proportion of conceptions resulting in legal abortion decreased from 21.8 per cent in 2008 to 21.0 per cent in 2009 , with a decrease in all age groups 


\section{Household' composition}

Households are defined as people who live and eat together or people who live alone. Families are defined by marriage, civil partnership or cohabitation or, where there are children in the household, child/parent relationships exist. Most households consist of a single family or someone living alone (as shown in Table 2). This first section looks at people living in private households and excludes those living in institutions such as care homes, prisons, hospitals and other communal establishments.

There were an estimated 25.3 million households in Great Britain in 2010, an increase of 1.4 million from 2001 and 9.0 million since 1961. The proportion of households with three or more people has fallen from 57 per cent in 1961 to 36 per cent in 2010. Consequently the average household size fell from 3.1 people in 1961 to 2.4 people in 2010, as seen in Table 1.

\section{Table 1 Households: ${ }^{1}$ by size}

\begin{tabular}{lrrrrrrr} 
Great Britain & \multicolumn{1}{c}{ Percentages } \\
\hline & 1961 & 1971 & 1981 & $\mathbf{1 9 9 1}$ & $\mathbf{2 0 0 1}$ & $\mathbf{2 0 1 0}$ \\
\hline One person & 12 & 18 & 22 & 27 & 29 & 29 \\
Two people & 30 & 32 & 32 & 34 & 35 & 35 \\
Three people & 23 & 19 & 17 & 16 & 16 & 16 \\
Four people & 19 & 17 & 18 & 16 & 14 & 14 \\
Five people & 9 & 8 & 7 & 5 & 5 & 4 \\
Six or more people & 7 & 6 & 4 & 2 & 2 & 2 \\
& & & & & & \\
All households (millions = 100\%) & 16.3 & 18.6 & 20.2 & 22.4 & 23.9 & 25.3 \\
Average household size (number of people) & 3.1 & 2.9 & 2.7 & 2.5 & 2.4 & 2.4 \\
\hline
\end{tabular}

1 Data are at Q2 (April-June) each year and are not seasonally adjusted. A household is a set of people who live and eat together or a person living alone.

Source: Census, Labour Force Survey, Office for National Statistics

Part of the decrease in average household size in Great Britain can be attributed to a reduction in the proportion of families with children and the decrease in the number of children within those families, as shown in Table 2. 


\section{Table 2 Households: ${ }^{1}$ by type of household and family}

Great Britain Percentages

\begin{tabular}{|c|c|c|c|c|c|c|}
\hline & 1961 & 1971 & 1981 & 1991 & 2001 & 2010 \\
\hline One person households & 12 & 18 & 22 & 27 & 29 & 29 \\
\hline \multicolumn{7}{|l|}{ One family households } \\
\hline \multicolumn{7}{|l|}{ Couple $^{2}$} \\
\hline No children & 26 & 27 & 26 & 28 & 29 & 28 \\
\hline 1-2 dependent children ${ }^{3}$ & 30 & 26 & 25 & 20 & 19 & 18 \\
\hline 3 or more dependent children ${ }^{3}$ & 8 & 9 & 6 & 5 & 4 & 3 \\
\hline Non-dependent children only & 10 & 8 & 8 & 8 & 6 & 6 \\
\hline \multicolumn{7}{|l|}{ Lone parent $^{2}$} \\
\hline Dependent children ${ }^{3}$ & 2 & 3 & 5 & 6 & 7 & 7 \\
\hline Non-dependent children only & 4 & 4 & 4 & 4 & 3 & 3 \\
\hline Two or more unrelated adults & 5 & 4 & 5 & 3 & 3 & 3 \\
\hline Multi-family households & 3 & 1 & 1 & 1 & 1 & 1 \\
\hline \multicolumn{7}{|l|}{ All households } \\
\hline (=100\%) (millions) & 16.3 & 18.6 & 20.2 & 22.4 & 23.9 & 25.3 \\
\hline
\end{tabular}

1 Data are at Q2 (April-June) each year and are not seasonally adjusted.

2 These households may contain individuals who are not family members. Couples include a small number of same-sex couples and civil partners.

3 Dependent children are children living with their parent(s) aged under 16, or aged 16 to 18 in full-time education, excluding all children who have a spouse, partner or child living in the household. These families may also contain nondependent children.

Source: Census, Labour Force Survey, Office for National Statistics

There was little change in the proportions of different types of families within households between 2001 and 2010. Over the longer term the proportion of households which consisted of one family with children decreased from 54 per cent to 37 per cent between 1961 and 2010. Over the same time period the proportion of households containing couples with one or two dependent children went down from 30 per cent to 18 per cent (from about 4.9 million to 4.6 million households) and those with 3 or more dependent children from 8 per cent to 3 per cent of all households (from about 1.3 million to 0.8 million households).

Another contributor to the reduction in average household size, as reported in Table 1, is the increase in the proportion of people living alone. In 2010, 29 per cent of all households in Great 
Britain contained just one person, the same proportion as in 2001, but a considerable increase since 1961 when only 12 per cent of households were one person living alone.

\section{People living in households}

This section examines in more detail the people living in households in the UK and compares changes between 2001 and 2010. In 2010 there were an estimated 61.4 million people living in households in the UK an increase of 3.1 million since 2001.

\section{Table $3 \quad$ People living in households: by type of household ${ }^{1}$}

United Kingdom

Millions and percentages

\begin{tabular}{|c|c|c|c|c|}
\hline & 2001 & 2010 & 2001 & 2010 \\
\hline & \multicolumn{2}{|c|}{ (Millions) } & \multicolumn{2}{|c|}{ (Percentages) } \\
\hline One person household & 7.0 & 7.5 & 12.0 & 12.3 \\
\hline Under 65 & 3.7 & 4.2 & 6.4 & 6.8 \\
\hline 65 or over & 3.3 & 3.4 & 5.7 & 5.5 \\
\hline One family households & 48.4 & 50.4 & 83.0 & 82.1 \\
\hline Couple $^{2}$ & 42.0 & 43.0 & 72.0 & 70.1 \\
\hline No children & 14.3 & 15.2 & 24.6 & 24.7 \\
\hline 1-2 dependent children ${ }^{3}$ & 17.1 & 17.5 & 29.3 & 28.6 \\
\hline 3 or more dependent children ${ }^{3}$ & 5.3 & 4.8 & 9.1 & 7.8 \\
\hline Non-dependent children only & 5.3 & 5.5 & 9.0 & 9.0 \\
\hline Lone parent ${ }^{2}$ & 6.4 & 7.4 & 11.0 & 12.0 \\
\hline Dependent children ${ }^{3}$ & 4.7 & 5.3 & 8.1 & 8.6 \\
\hline Non-dependent children only & 1.7 & 2.1 & 2.9 & 3.4 \\
\hline Two or more unrelated adults & 1.9 & 2.2 & 3.3 & 3.6 \\
\hline Multi-family households & 1.0 & 1.3 & 1.7 & 2.1 \\
\hline All people in households & 58.3 & 61.4 & 100.0 & 100.0 \\
\hline
\end{tabular}

1 Data are at Q2 (April-June) each year and are not seasonally adjusted.

2 These households may contain individuals who are not family members. Couples data for 2010 include a small number of same-sex couples and civil partners.

3 Dependent children are children living with their parent(s) aged under 16, or aged 16 to 18 in full-time education, excluding all children who have a spouse, partner or child living in the household. These families may also contain nondependent children.

Source: Census, Labour Force Survey, Office for National Statistics 
Between 2001 and 2010 there were increases in the numbers of people living in all types of household in the UK apart from that consisting of a couple with three or more dependent children where there was a decrease of nearly half a million.

There were some changes in the proportions of households of different type: there were smaller proportions of people living in couple households with dependent and non-dependent children in 2010 as compared to 2001, and larger proportions living in lone parent, multi-family and one person, households. This reflects the trend towards fewer families with children and families with fewer children as discussed earlier for Great Britain.

In the UK between 2001 and 2010 there was an increase in the both the estimated number of people living alone from 7.0 million to 7.5 million and the proportion that these formed of all households from 12.0 per cent to 12.3 per cent (Table 3 ).

Not only have there been changes in the number and proportion of single person households but there are differences between age groups. In 2010 in the UK 55 per cent of all people living alone were under 65, an increase from 53 per cent in 2001.

\section{Figure 1 Proportion of people living alone: by age group}

United Kingdom

Percentages

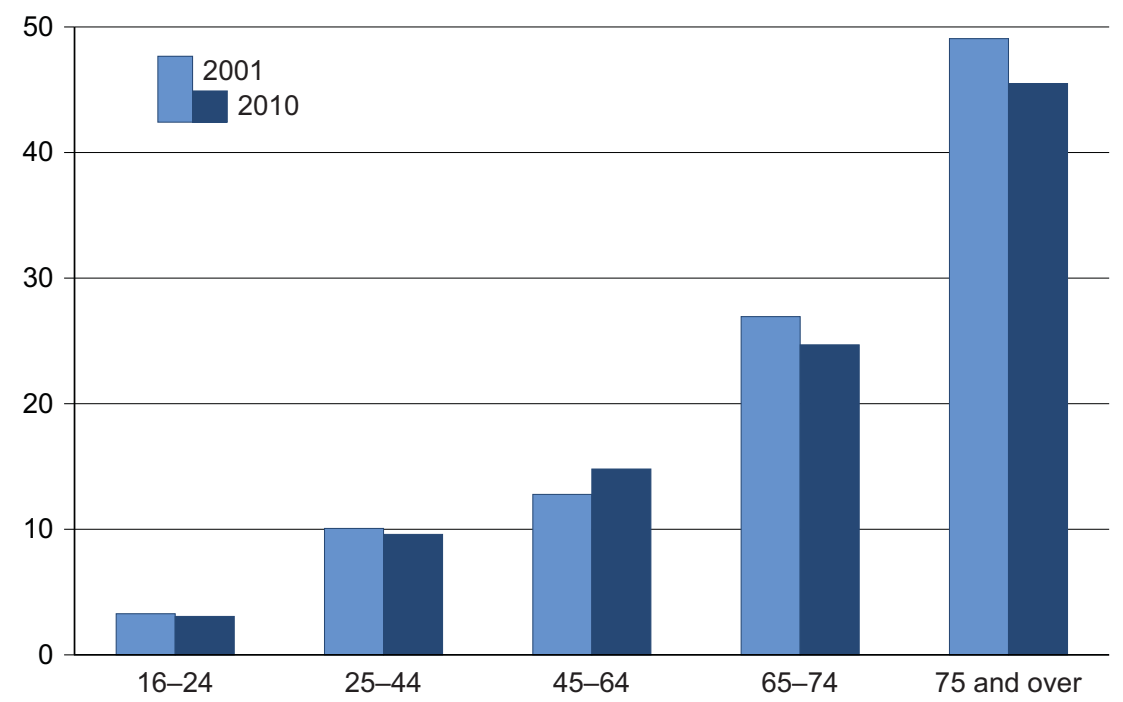

Source: Office for National Statistics

As age increases so the proportion of the age group living alone also increases. In 2010 in the UK, around three per cent of those aged 16 to 24 lived alone compared to around 25 per cent of those aged 65 to 74 and over 45 per cent of those aged 75 and over. There had been slight changes in the proportions of the age groups who were living alone between 2001 and 2010 with decreases for all age groups apart from those aged 45 to 64 . The largest changes were in those aged 75 and over which had decreased from 49 per cent of the age group in 2001 to 45 per cent in 2010 and those aged 65 to 74 which had decreased from 27 per cent to 25 per cent of the age group (Figure 1). 
The decrease in the proportion of the older age groups living alone is linked to the fall in the proportions who are widowed. In England and Wales between 2001 and 2009 the estimated percentage of widowed persons changed from 20 per cent to 15 per cent of those aged 65-74 and from 51 per cent to 46 per cent of those aged 75 and over (ONS 2011a).

\section{Families}

The previous sections examined the composition of households in Great Britain and the UK. This section describes the different types of family in the UK and the people who live in them. In 2010 there were about 17.9 million families in the UK, an estimated increase of 0.9 million (5.6 per cent) since 2001. The growth in the number of families between 2001 and 2010 is made up of increases in the numbers of cohabiting couple by 0.6 million and lone parent families by 0.4 million offset by a reduction in the number of married couple families by 0.1 million. Between 2001 and 2010 the number of people living in families increased by 4.1 per cent from 48.8 million to 50.8 million (Table 4).

\section{Table $4 \quad$ Families and number of people living in families: by family type}

\begin{tabular}{|c|c|c|c|c|}
\hline & \multicolumn{2}{|c|}{ Families } & \multicolumn{2}{|c|}{ People in families } \\
\hline & 2001 & 2010 & 2001 & 2010 \\
\hline Married couple family & 72.4 & 68.0 & 74.7 & 70.2 \\
\hline Civil partner family & - & 0.2 & - & 0.2 \\
\hline Cohabiting couple family & 12.5 & 15.3 & 11.7 & 14.7 \\
\hline Same sex cohabiting couple family & 0.3 & 0.3 & 0.2 & 0.2 \\
\hline Lone parent family & 14.8 & 16.2 & 13.4 & 14.7 \\
\hline Lone mother family & 12.7 & 14.1 & 11.7 & 12.9 \\
\hline Lone father family & 2.1 & 2.1 & 1.7 & 1.8 \\
\hline $\begin{array}{l}\text { All families and people in families (millions = } \\
100 \% \text { ) }\end{array}$ & 17.0 & 17.9 & 48.8 & 50.8 \\
\hline
\end{tabular}

Source: Labour Force Survey, Office for National Statistics

Married couple families were the most common in the UK each of these two years although there had been a decrease from 72.4 to 68.0 per cent in this type of family between 2001 and 2010 . There had been an increase between 2001 and 2010 in the proportion of families which were cohabiting couples from 12.5 per cent to 15.3 per cent, and in lone parent families from 14.8 per cent to 16.2 per cent. Almost all the growth in lone parent families was in those headed by a lone mother. 
Of all those living in families just over 70 per cent (35.7 million) lived in a married couple family in 2010, while the proportions living in cohabiting families and lone parent families were each nearly 15 per cent or 7.5 million people.

The introduction of Civil Partnerships in 2004 has resulted in approximately 45,000 civil partner families by 2010. In addition in 2010 there were approximately 51,000 same sex cohabiting families.

In 2010 there were 7.7 million families with dependent children iii, an increase of 0.3 million (3.7 per cent) since 2001. The number of dependent children living in families in 2010 was 13.3 million a slight decrease of 0.1 per cent since 2001.

\section{Table 5 Families ${ }^{1}$ with dependent children $^{2}$}

\begin{tabular}{|c|c|c|c|c|}
\hline & \multicolumn{2}{|c|}{ Families } & \multicolumn{2}{|c|}{ Dependent children } \\
\hline & 2001 & 2010 & 2001 & 2010 \\
\hline Married couple family & 65.4 & 60.4 & 68.0 & 63.0 \\
\hline One child & 24.1 & 24.4 & 13.4 & 14.1 \\
\hline Two children & 29.5 & 26.3 & 32.8 & 30.3 \\
\hline Three or more children & 11.8 & 9.8 & 21.7 & 18.6 \\
\hline Cohabiting couple family & 10.9 & 14.0 & 10.1 & 13.4 \\
\hline One child & 5.8 & 7.3 & 3.2 & 4.2 \\
\hline Two children & 3.6 & 4.8 & 4.0 & 5.5 \\
\hline Three or more children & 1.6 & 1.9 & 2.9 & 3.7 \\
\hline Lone parent family & 23.6 & 25.5 & 21.9 & 23.6 \\
\hline One child & 12.6 & 14.6 & 7.0 & 8.4 \\
\hline Two children & 7.6 & 7.8 & 8.5 & 9.1 \\
\hline Three or more children & 3.3 & 3.1 & 6.3 & 6.1 \\
\hline All families & 100.0 & 100.0 & 100.0 & 100.0 \\
\hline One child & 42.5 & 46.3 & 23.7 & 26.8 \\
\hline Two children & 40.8 & 38.9 & 45.4 & 44.9 \\
\hline Three or more children & 16.7 & 14.8 & 30.9 & 28.3 \\
\hline
\end{tabular}

1 Excludes a small number of Civil Partnership and same sex cohabiting couple families.

2 Excludes dependent children who do not live in families.

Source: Labour Force Survey, Office for National Statistics 
The majority of dependent children in the UK live in families of which there are three main types: a married couple, a cohabiting couple or a lone parent family. The proportions of these types of family with dependent children have changed between 2001 and 2010. Married couple families decreased from 65.4 per cent of all families with dependent children in 2001 to 60.4 per cent in 2010 (Table 5). The numbers of these families had also gone down from 4.8 million in 2001 to 4.6 million 2010. The proportion of cohabiting couple families with dependent children increased between 2001 and 2010 from 10.9 per cent to 14.0 per cent, and lone parent families from 23.6 per cent to 25.5 per cent of all families with dependent children.

Of all dependent children living in families, 63.0 per cent (8.4 million) lived in a married couple family in 2010 a decrease from 68.0 per cent (9.0 million) in 2001 . The proportion living in cohabiting couple families increased from 10.1 per cent (1.3 million) in 2001 to 13.4 per cent (1.8 million) in 2010. Over the same time period the proportion of dependent children living in lone parent families increased from 21.9 per cent to 23.6 per cent (2.9 million to 3.1 million).

At the time of the survey in 2010 families with one dependent child were the most common, comprising 46.3 per cent of all families with dependent children, an increase from 42.5 per cent in 2001. Over half of all cohabiting couple and lone parent families had a single dependent child. However, for married couple families the most frequent number of dependent children was two. The proportion of all families with three or more dependent children decreased from 16.7 per cent in 2001 to 14.8 per cent in 2010 , an indicator of the decrease in family size for families with dependent children. Note that all these types of family could also have non-dependent children.

\section{Family formation}

The previous sections showed estimates of households and families at specific points in time. The next sections discuss the events which can cause changes to household and family types, such as marriage, civil partnership, divorce and dissolution and births.

The Marriage Act 1836 and the Registration Act 1836 came into force in 1837 in England and Wales and provided the statutory basis for regulating and recording marriages. There were 118,000 marriages registered in 1838, the first full year of civil registration in England and Wales. Annual numbers of marriages rose steadily from the 1840 s to the 1940 s, apart from peaks and troughs around the two world wars.

The provisional number of marriages registered in England and Wales in 2009 was 231,490 (Figure 2). This currently represents the lowest numbers of marriages in England and Wales since $1895(228,204)$. However, it is estimated that a further one per cent of 2009 marriage returns will be received from register offices and the clergy over the next year allowing final figures to be published (ONS, 2011b). It is therefore expected that final 2009 marriage figures will be similar in total to $2008(235,794)$. 


\section{Figure 2 Marriages: by previous marital status}

\section{England and Wales}

Thousands

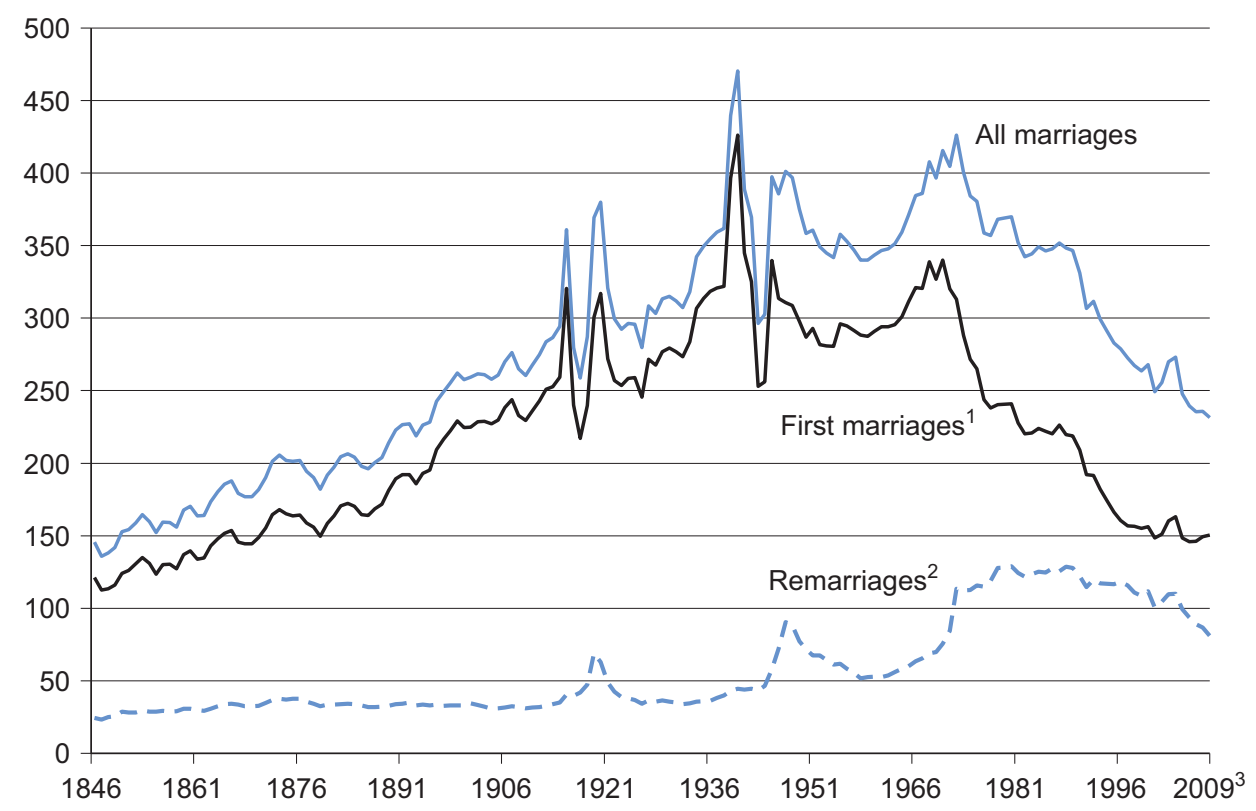

1 For both parties

2. For one or both parties.

3. Figures for 2009 are provisional.

Source: Office for National Statistics (ONS 2009; 2011c)

The number of marriages in England and Wales that were the first for both partners peaked in 1940 at 426,100 when 91 per cent of all marriages were the first for both partners. First marriages fell below three-quarters (73 per cent) of all marriages in 1972 and continued to decrease, reaching a low of 58 per cent in 1997. Provisional figures for 2009 show that there were around 150,600 marriages which were first for both partners, almost two-thirds (65 per cent) of all marriages. The last time the proportion of marriages that were first marriages was this high was in 1980.

Remarriages rose by about a third between 1971 and 1972, following the introduction of the Divorce Reform Act 1969 in England and Wales, and then levelled off. Provisional estimates for 2009 show that 35 per cent of all marriages $(80,900)$ were remarriages for one or both parties. This is a decrease since 2008 and a continuation of the slight downward trend since 2004.

In England and Wales, the number of unmarried adults rose between 2008 and 2009 (ONS 2011a; 2011d), but the provisional number choosing to marry remained stable, producing the lowest marriage rates since they were first calculated in 1862. In 2009, the provisional marriage rate for men was 21.3 men marrying per 1,000 unmarried men aged 16 and over, down from 22.0 in 2008 . The provisional marriage rate for women in 2009 was 19.2 women marrying per 1,000 unmarried women aged 16 and over, down from 19.9 in 2008 (ONS, 2011b).

In Scotland, the number of marriages decreased from 28,903 in 2008 to 27,524 in 2009 , a fall of 4.8 per cent, while in Northern Ireland the number of marriages decreased by 6.8 per cent to 7,931 (ONS 2011e). 
Since 1999, there have been more civil ceremonies in England and Wales than religious ceremonies. Of the 231,490 marriages that were registered in England and Wales in 2009, two thirds (67 per cent) were solemnised in civil as opposed to religious ceremonies and 48 per cent of all marriages were in Approved Premises. This is a considerable increase since 1981 when only 49 per cent of all marriages were civil ceremonies (ONS 2011c). As well as the changes in the type and place of ceremony there has also been a change in the seasonal distribution of marriages: in 198162 per cent of marriages took place between April and September but this had risen to 70 per cent in 2009 (ONS, 2011c).

The Civil Partnership Act 2004 came into force on 5 December 2005 in the UK; when couples could give notice of their intention to form a civil partnership ${ }^{\text {iv }}$. The Act enables same-sex couples aged 16 and over to obtain legal recognition of their relationship. The first day that couples could formally form a partnership was 19 December 2005 in Northern Ireland, 20 December 2005 in Scotland and 21 December 2005 in England and Wales. The total number of partnerships formed since the Civil Partnership Act came into force in December 2005 up to the end of 2009 is 40,237. The highest number of civil partnerships registered in the UK in a month was in December 2005 $(1,953)$ (ONS, 2010a). The high number of partnerships formed in this month, and throughout the following 12 months, reflected the number of same-sex couples in long-term relationships who took advantage of the opportunity to formalise their relationship as soon as possible after the legislation was implemented. 


\section{Figure 3 Civil partnerships: by sex}

United Kingdom

Thousands

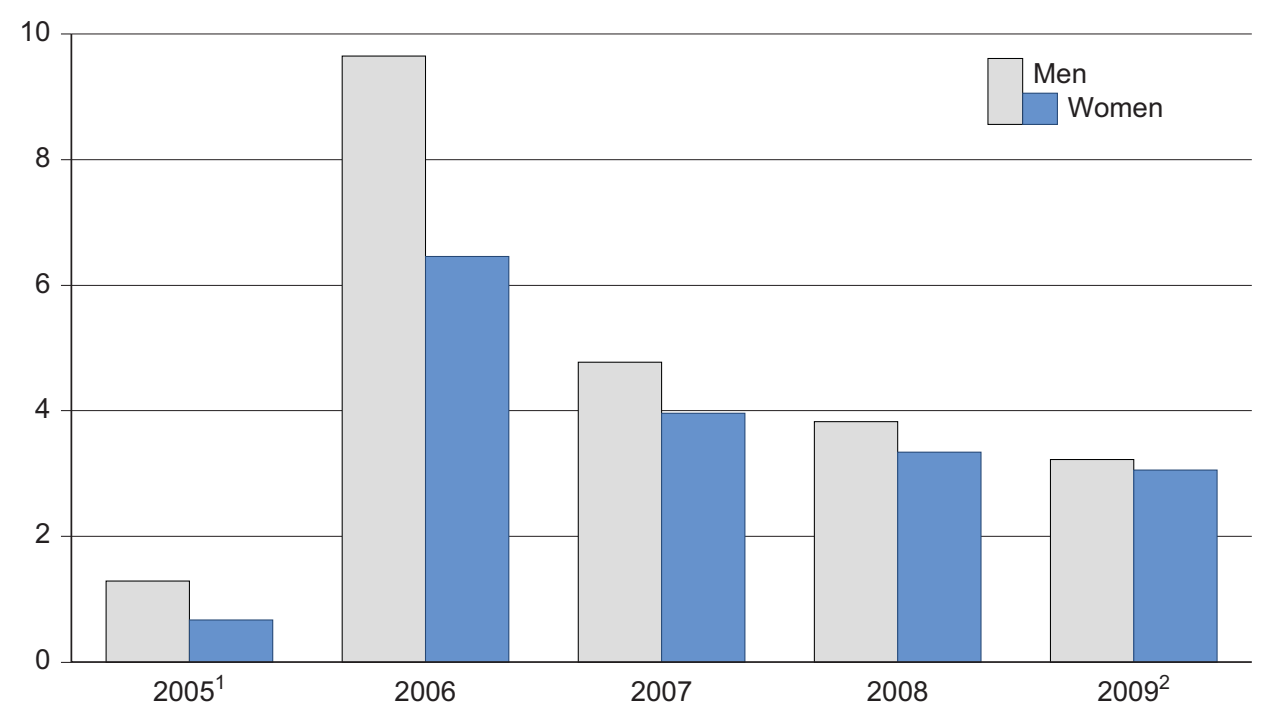

1 In 2005 there were only 11 days in England and Wales and 12 days in Scotland on which couples could normally register a partnership.

2 Figures for the UK for 2009 are provisional.

Sources: Office for National Statistics, General Register Office for Scotland, Northern Ireland Statistics and Research Agency (ONS, 2010a)

Provisionally, there were a total of 6,281 civil partnerships registered in the UK in 2009, a fall of 12.4 per cent on the previous year continuing the trend seen in 2007. In 2009 3,227 (51 per cent) were male and 3,054 were female partnerships (Figure 3).

There were decreases in the number of civil partnerships in England (from 6,276 to 5,443), Wales (from 282 to 244) and Scotland (from 525 to 498) between 2008 and 2009. However, the number of civil partnerships in Northern Ireland increased from 86 to 96 (ONS, 2010a).

\section{Divorces and dissolution}

Another way in which family structures change is following divorce or, for civil partnerships, dissolution. Between 1918 and 1938 the number of divorces each year in England and Wales gradually increased from 1,100 to 6,300 (Figure 4). Following the Act of Parliament in 1938 that extended the grounds on which divorce was allowed, numbers increased considerably throughout the 1940 s, to a peak of around 60,300 in 1947. Although the number of divorces then fell to 22,700 in 1958, there was a further increase during the 1960 s. 


\section{Figure $4 \quad$ Number of couples divorcing}

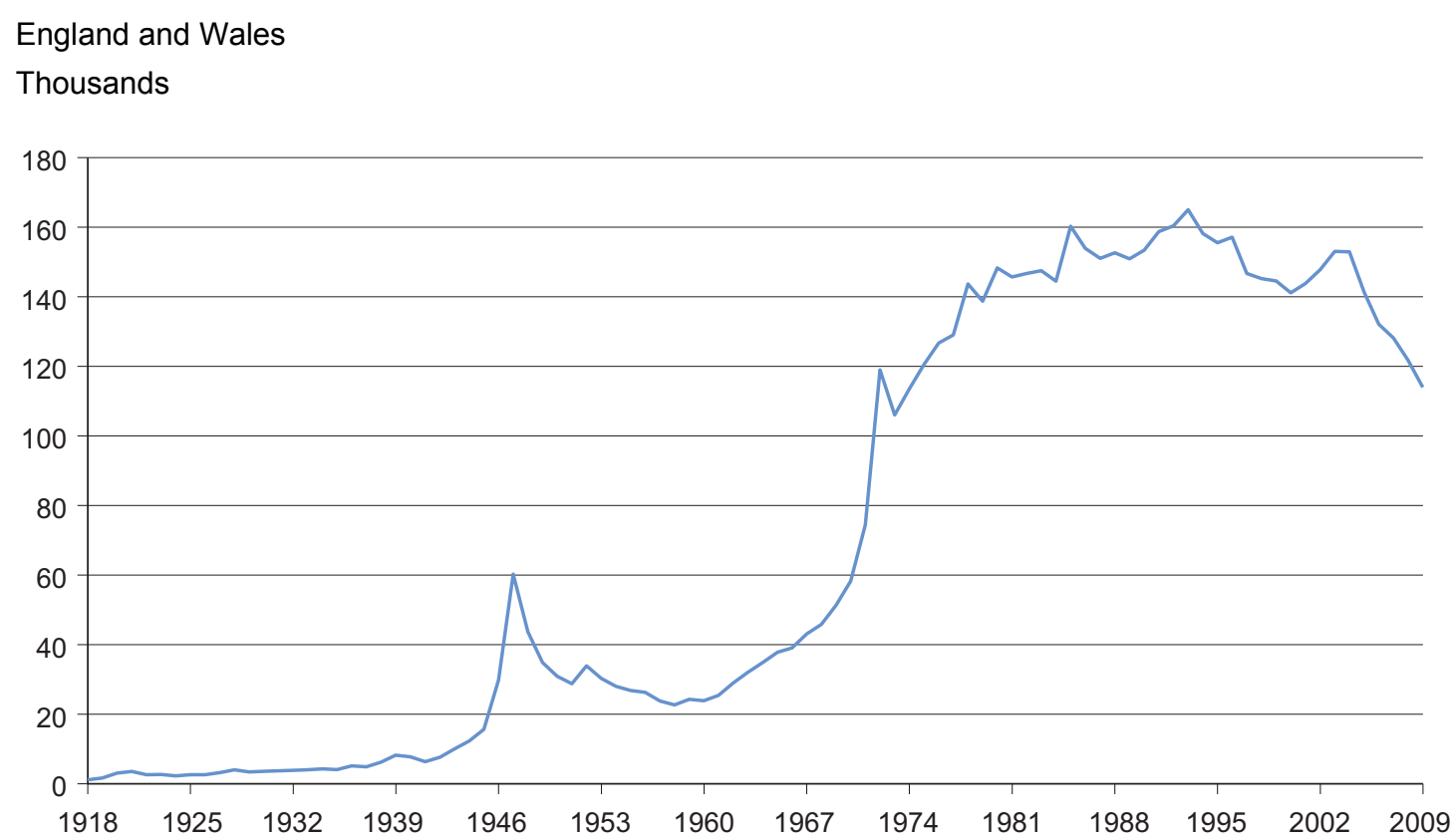

Source: Office for National Statistics (ONS, 2011f)

The Divorce Reform Act of 1969, which was subsequently consolidated into the Matrimonial Causes Act 1973, had a considerable impact on divorce numbers in England and Wales. In 1972 there were 119,000 divorces, an increase of almost 60 per cent on the previous year. From 1972 onwards, there was a generally upward trend in divorces in England and Wales, reaching the highest recorded number of 165,000 in 1993.

The numbers of divorces were variable between 1993 and 2002, but there has been a consistent downward trend from 2003 to 2009. In 2009 there were about 113,900 divorces in England and Wales compared with 121,700 in 2008 , a decrease of 6.4 per cent.

In Scotland, there were less than 10,200 divorces registered in 2009/10, a fall of 9.8 per cent on the previous year. In Northern Ireland in 2009, less than 2,200 divorces were recorded, a decrease of 21.5 per cent compared with the previous year (Scottish Government, 2010a; NISRA, 2010a).

In order to obtain the dissolution of a civil partnership, a couple must have been in a registered partnership, or a recognised foreign relationship, for at least 12 months. In 2009 there were 351 civil partnership dissolutions granted in the UK, 127 to male couples and 224 to female couples, an increase from 180 in 2008 and 41 in 2007 (ONS, 2010b).

As already discussed family type is changed when divorce occurs, and when a divorcing couple have children, this affects the family type in which those children live. There has been a considerable change not only in the number of children living in families affected by divorce but also in the distribution of their ages. Between 1989 and 2009 the total number of children of divorcing couples of all ages decreased from just over 216,000 to less than 154,000; this decrease is partly because of the overall decrease in the number of divorces and partly because the average number of children involved in each divorce had reduced (ONS 2011g). 


\section{Figure $5 \quad$ Number of children ${ }^{1}$ of divorced couples: by age $^{2}$ group}

\section{England and Wales}

Thousands

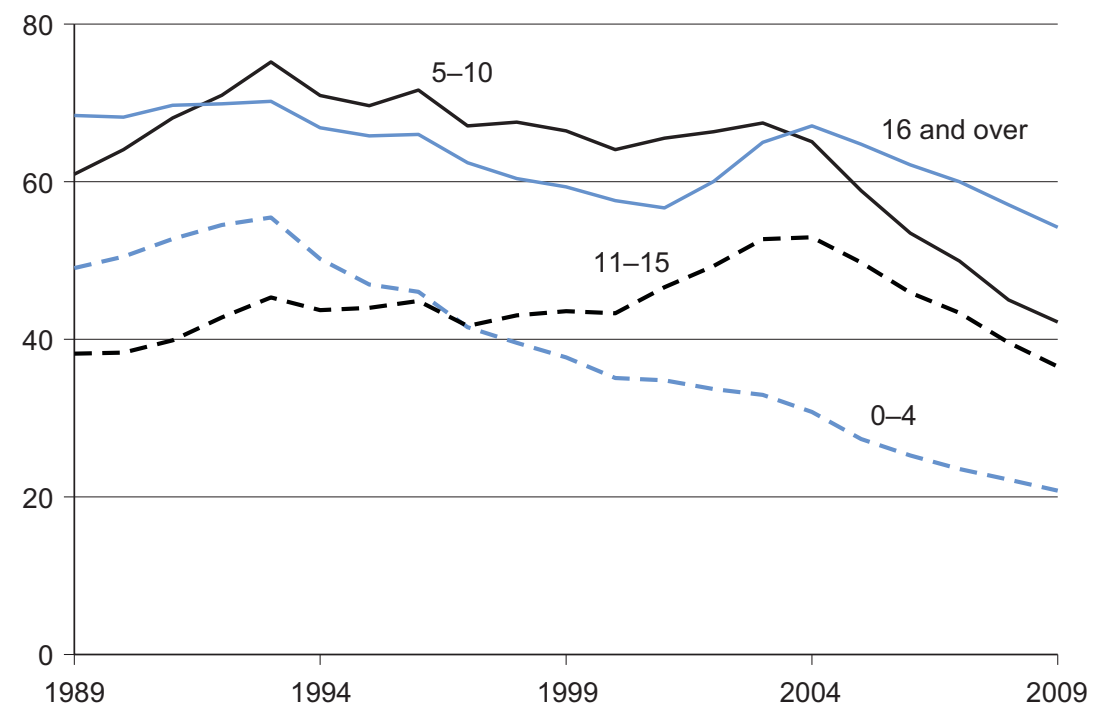

1 Children are those treated as children of the family, and can include children born outside marriage, children of previous marriages, adopted and step children.

2 Ages are those at petition to divorce.

Source: Office for National Statistics (ONS, 2011g)

Not only was there a decrease in the total number of children affected by divorce, but there was a change in the ages at which children were affected by divorce. This is particularly noticeable for children aged 0 to 4 , where, after an increase to about 55,500 in 1993, numbers fell in each year to reach 20,800 in 2009 . By 2004 , the highest number of children who were affected by divorce were those aged 16 and over. From 2004 onwards numbers in each of the age groups decreased in line with the decrease in the overall number of divorces (Figure 5).

\section{Births}

One of the largest changes over time, as noted above, is in the types of family which have dependent children; there has been a decrease in the proportion living in married couple families and an increase in the proportion that are living in cohabiting couple and lone parent families. This section examines changes in the numbers of children born within and outside marriage together with the changes in the ages of their mothers. There is also a discussion of the differences over time in the registration of their births and how this relates to the change in the types of family with dependent children.

The number of births in England and Wales increased for seven successive years between 2001 and 2008 , rising from 594,600 in 2001 to 708,700 in 2008 . However, the number of live births decreased by about 2,500 to 706,200 in 2009 . 


\section{Table $6 \quad$ Live births: by age of mother and registration type ${ }^{1}$}

England and Wales

Numbers of births

\begin{tabular}{|c|c|c|c|c|c|c|c|}
\hline & \multicolumn{6}{|c|}{ Age of mother at birth } & \multirow[b]{2}{*}{ All ages } \\
\hline & Under 20 & $20-24$ & $25-29$ & $30-34$ & $35-39$ & 40 and over & \\
\hline \multicolumn{8}{|l|}{ All } \\
\hline 1971 & 82,600 & 285,700 & 247,200 & 109,600 & 45,200 & 12,700 & 783,200 \\
\hline $1981^{2}$ & 56,600 & 194,500 & 215,800 & 126,600 & 34,200 & 6,900 & 634,500 \\
\hline 1991 & 52,400 & 173,400 & 248,700 & 161,300 & 53,600 & 9,800 & 699,200 \\
\hline 2001 & 44,200 & 108,800 & 159,900 & 178,900 & 86,500 & 16,300 & 594,600 \\
\hline 2008 & 44,700 & 136,000 & 193,000 & 192,500 & 116,200 & 26,400 & 708,700 \\
\hline 2009 & 43,200 & 136,000 & 194,100 & 191,600 & 114,300 & 27,000 & 706,200 \\
\hline \multicolumn{8}{|c|}{ Outside marriage } \\
\hline 1971 & 21,600 & 22,000 & 11,500 & 6,300 & 3,200 & 1,100 & 65,700 \\
\hline $1981^{2}$ & 26,400 & 28,800 & 14,300 & 7,900 & 27,300 & 900 & 81,000 \\
\hline 1991 & 43,400 & 77,800 & 52,400 & 25,700 & 9,800 & 2,100 & 211,300 \\
\hline 2001 & 39,500 & 68,100 & 56,800 & 45,200 & 23,300 & 5,100 & 238,100 \\
\hline 2008 & 42,000 & 97,700 & 82,600 & 54,400 & 34,600 & 9,500 & 320,800 \\
\hline 2009 & 40,900 & 100,100 & 85,600 & 55,800 & 34,100 & 9,600 & 326,200 \\
\hline \multicolumn{8}{|c|}{ Within marriage } \\
\hline 1971 & 61,100 & 263,700 & 235,700 & 103,400 & 42,100 & 11,600 & 717,500 \\
\hline $1981^{2}$ & 30,100 & 165,700 & 201,500 & 118,700 & 31,500 & 6,000 & 553,500 \\
\hline 1991 & 8,900 & 95,600 & 196,300 & 135,500 & 43,800 & 7,700 & 487,900 \\
\hline 2001 & 4,600 & 40,700 & 103,100 & 133,700 & 63,200 & 11,100 & 356,500 \\
\hline 2008 & 2,700 & 38,200 & 110,400 & 138,100 & 81,600 & 16,900 & 387,900 \\
\hline 2009 & 2,300 & 35,900 & 108,500 & 135,800 & 80,200 & 17,400 & 380,100 \\
\hline
\end{tabular}

1. The Human Fertilisation and Embryology Act 2008 contained provisions enabling two females in a same-sex couple to register a birth from 1st September 2009 onwards. Due to the small numbers in 2009, births registered to a same-sex couple in a civil partnership (22 in 2009) are included with marital births while births registered to a same-sex couple outside a civil partnership (2 in 2009) are included with births outside marriage.

2. For 1981 data the processing was delayed due to the late submission of registrations. As a result the data for 1981 is estimated and figures for age of mother are based on a ten per cent sample.

Source: Office for National Statistics (ONS, 2010c)

The average age for women giving birth in England and Wales has increased from just over 26 and a half years in 1971 to just under 29 and a half years in 2009 (ONS, 2010c) and this is reflected in the age distribution in Table 6. In 1971, nearly four out of five of all live births (79 per cent) were to women aged less than 30: by 2009 just over half of all live births (53 per cent) were to women of this age. The number of live births decreased for women in each of the three age groups under 20 , 
20 to 24 and 25 to 29 and increased in women aged 30 to 34,35 to 39 and 40 and over between 1971 and 2009.

In 1971 there were 65,700 live births outside marriage in England and Wales, 8.4 per cent of all live births in that year. By 1991 the number of live births outside marriage had risen to 211,300, more than 30.2 per cent of all live births in that year. Live births outside marriage have continued to increase both numerically and as a proportion of all births reaching 326,200 (46.2 per cent) in 2009 , an increase of about 5,400 (1.7 per cent) compared to 2008 and nearly five times as many as were born outside marriage in 1971. Over the same time period the number of live births within marriage had decreased by 47 per cent from 717,500 to 380,100 (Table 6).

However, the increases and decreases in overall births, and those within and outside marriage were not the same for all age groups. The age distribution of women for births within marriage reflects the increase already mentioned in the average age at birth and also in average age for women at marriage. There have been considerable decreases in the number of births within marriage for each of the three age groups under 20, 20 to 24 and 25 to 29 . For example, the number of births within marriage in the under 20 age group decreased from 61,100 in 1971 to 2,300 in 2009 (a decrease of 58,800 or 96 per cent). In the older age groups there have been increases in births within marriage: for example in the 35 to 39 age group the increase between 1971 and 2009 was 38,000 live births (from 42,100 to 80,200 or 91 per cent).

By contrast, for births outside marriage there have been increases in the number of live births in all age groups, particularly since 2001 . 


\section{Table $7 \quad$ Live births outside marriage: by registration type ${ }^{1}$}

\begin{tabular}{|c|c|c|c|}
\hline & $\begin{array}{r}\text { Joint registration same } \\
\text { address }^{2}\end{array}$ & $\begin{array}{r}\text { Joint registration different } \\
\text { addresses }^{2}\end{array}$ & Sole Registration \\
\hline 1971 & & 45.5 & 54.5 \\
\hline $1981^{3}$ & & 58.2 & 41.8 \\
\hline 1991 & 54.6 & 19.8 & 25.6 \\
\hline 2001 & 63.2 & 18.4 & 18.4 \\
\hline 2008 & 65.5 & 20.3 & 14.2 \\
\hline $2009^{4}$ & 65.7 & 20.9 & 13.4 \\
\hline
\end{tabular}

1 Births outside marriage can be registered by both parents (joint) or by the mother alone (sole).

2 Usual address(es) of parents.

3 For 1981 data the processing was delayed due to the late submission of registrations. As a result the data for 1981 is estimated and figures for age of mother are based on a ten per cent sample. Figures have been rounded to the nearest ten.

4. The Human Fertilisation and Embryology Act 2008 contained provisions enabling two females in a same-sex couple to register a birth from 1st September 2009 onwards. Due to the small numbers in 2009, births registered to a same-sex couple outside a civil partnership (2 in 2009) are included with births outside marriage.

Source: Office for National Statistics (ONS, 2010c; 2010d)

There have also been changes over time in the registration status of children born outside marriage. In 197145.5 per cent of children born outside marriage were registered jointly (Table 7). When data began to be reported about the address status of those who had jointly registered births outside marriage in 1991, nearly three quarter (74.4 per cent) were jointly registered and more than half of these (54.6 per cent of all registrations outside of marriage) were from couples living at the same address (for more information about children in cohabiting couple families see Figure 5). By 2009, 65.7 per cent of births outside of marriage were registered by parents living at the same address, 20.9 per cent were registered by parents living at different addresses and 13.4 per cent were solely registered. The number of sole registrations of births has remained fairly stable between 2001 and 2009, varying from 43,000 to 46,000 (ONS, 2010d).

In Scotland, the proportion of births outside marriage rose to 50 per cent for the first time in 2008 and increased slightly in 2009 (General Register Office for Scotland, 2010). In Northern Ireland in 2009, there were almost 10,000 births outside marriage, around 40 per cent of all births (NISRA, 2010b). 


\section{Conceptions and Abortions}

Information about conceptions ${ }^{v}$ also shows a change in age structure. Provisional estimates in 2009 are that there were 896,300 conceptions in England and Wales, an increase of nearly 8,000 ( 0.9 per cent) from 888,600 in 2008 . The number of conceptions in 2009 was also higher than in 1991 and 2001. There was an increase in the overall rate of conception between 2008 and 2009 of one additional conception per 1,000 women (from 80 to 81 conceptions per 1,000 women aged 15 to 44 , see footnote 4 to table 8 ).

\section{Table 8 Conceptions: ${ }^{1}$ by age of woman at conception}

England and Wales ${ }^{2}$

\begin{tabular}{|c|c|c|c|c|c|c|c|c|c|}
\hline & \multicolumn{8}{|c|}{ Age of woman at conception } & \multirow[b]{2}{*}{ All ages } \\
\hline & Under 16 & Under 18 & Under 20 & $20-24$ & $25-29$ & $30-34$ & $35-39$ & $\begin{array}{r}40 \\
\text { and over }\end{array}$ & \\
\hline \multicolumn{10}{|c|}{ Numbers (thousands) } \\
\hline 1991 & 7.5 & 40.1 & 101.6 & 233.3 & 281.5 & 167.5 & 57.6 & 12.1 & 853.7 \\
\hline 2001 & 7.9 & 41.0 & 96.0 & 161.6 & 199.3 & 196.7 & 92.2 & 17.8 & 763.7 \\
\hline 2008 & 7.6 & 41.4 & 103.3 & 198.5 & 237.8 & 207.1 & 115.6 & 26.5 & 888.6 \\
\hline $2009^{3}$ & 7.2 & 38.3 & 97.9 & 199.5 & 242.2 & 213.3 & 116.5 & 26.8 & 896.3 \\
\hline \multicolumn{10}{|c|}{ Rates (conceptions ${ }^{4}$ per thousand women in age-group) } \\
\hline 1991 & 8.9 & 44.6 & 64.1 & 120.2 & 135.1 & 90.1 & 34.4 & 6.6 & 77.7 \\
\hline 2001 & 8.0 & 42.7 & 60.8 & 102.5 & 114.2 & 96.7 & 44.3 & 9.6 & 70.3 \\
\hline 2008 & 7.8 & 40.7 & 60.1 & 108.7 & 133.2 & 121.7 & 58.1 & 12.6 & 79.9 \\
\hline $2009^{3}$ & 7.5 & 38.3 & 57.3 & 108.5 & 133.8 & 125.9 & 60.1 & 12.8 & 80.9 \\
\hline \multicolumn{10}{|c|}{ Percentage terminated by abortion } \\
\hline 1991 & 51.1 & 39.9 & 34.5 & 22.2 & 13.4 & 13.7 & 22.0 & 41.6 & 19.4 \\
\hline 2001 & 55.8 & 45.7 & 40.4 & 29.7 & 18.4 & 14.6 & 20.4 & 34.6 & 23.2 \\
\hline 2008 & 61.5 & 49.4 & 42.4 & 28.0 & 17.4 & 12.8 & 16.3 & 30.0 & 21.8 \\
\hline $2009^{3}$ & 59.8 & 48.8 & 41.9 & 27.1 & 16.5 & 12.4 & 15.8 & 29.1 & 21.0 \\
\hline
\end{tabular}

1 Conception figures are estimates derived from birth registrations and abortion notifications.

2 Data are for residents of England and Wales.

3 Figures for 2009 are provisional.

4 Revised mid-2002 to mid-2008 population estimates published on 13 May 2010 have been used in the calculation of conception rates. Figures may therefore differ from those published previously. Rates for women of all ages, under 16 , under 18, under 20 and 40 and over are based on the population of women aged 15-44, 13-15, 15-17, 15-19 and 40-44 respectively.

Source: Office for National Statistics (ONS, 2011h)

However, these increases were not uniform across age groups. For all age groups from 25 to 29 to those aged 40 and over there were increases between 2008 and 2009 in the number of 
conceptions and in the rates of conception per 1,000 women. For women in the under 20 age group (and the constituent parts of women aged under 18 and under 16) there were decreases in both the numbers and rates of conception between 2008 and 2009. For the age group 20-24 there was a slight increase in the number of conceptions over this time period, but a slight decrease in the rate of conception, which can be explained by an increase in the number of women in this age group.

Over the longer time period of 1991 to 2009 there were also increases in the overall number and rates of conception, but the difference in the age groups is more marked. While there was an overall increase of an estimated 42,600 in the number of conceptions between 1991 and 2009, this was the result of a decrease of approximately 76,800 conceptions in women under 30 and an increase of 119,400 in conceptions in women over 30 and over.

Proportions of conceptions resulting in legal abortion were highest in the lower age groups: 48.8 per cent of conceptions in women under 18 and 59.8 per cent in girls aged less than 16 led to a legal abortion according to provisional estimates for 2009. The percentage of all conceptions which were terminated by legal abortion decreased from 21.8 per cent in 2008 to 21.0 per cent in 2009 with a decrease in the percentages in all age groups.

The overall percentage of conceptions leading to a legal abortion increased from 19.4 per cent to 21.0 per cent between 1991 and 2009. However, the largest increases over this time period were in the younger age groups which include girls and women up to the age of 30 . For those aged 30 and over, there were decreases in all age groups, with a particularly marked fall in the 40 and over age group from 41.6 per cent in 1991 to 29.1 per cent in 2009.

In Scotland, provisional figures for 2009 show that there were a total of 12,950 abortions performed in Scotland for Scottish residents, a decrease of 6.0 per cent since 2008. The rate per thousand women aged 15 to 44 had decreased from 13.2 to 12.4 (Scottish Government, 2010b).

In Northern Ireland, abortion is illegal and is only considered lawful in exceptional circumstances. As there are such a small number of abortions, and in order to protect patient confidentiality, there are no comparable conception figures for Northern Ireland. 


\section{References}

General Register Office for Scotland (2010). Live births, numbers and percentages, by marital status of parents and type of registration, Scotland, 1974 to 2009 . Available at www.gro-scotland.gov.uk/statistics/theme/vitalevents/general/ref-tables/2009/births.html

NISRA (2010a). Additional Tables for Marriages, Divorces and Civil Partnerships in Northern Ireland, 2009. Available at www.nisra.gov.uk/demography/default.asp25.htm

NISRA (2010b). Live births by number of previous children and marital status of parents, 1976 to 2009. Available at www.nisra.gov.uk/demography/default.asp98.htm

ONS (2009). Historic marriage tables: Previous marital status. Available at www.statistics.gov.uk/statbase/Product.asp?vlnk=581

ONS (2010a). Civil partnerships formations data. Available at www.statistics.gov.uk/StatBase/Product.asp?vlnk=14675\&Pos=4\&ColRank=1\&Rank=272

ONS (2010b). Civil partnerships dissolutions data. Available at www.statistics.gov.uk/StatBase/Product.asp? vlnk=14675\&Pos=4\&ColRank=1\&Rank=272

ONS (2010c). Characteristics of Mother 1 2009: 21/10/10. Available at www.statistics.gov.uk/statbase/Product.asp?vlnk=14408

ONS (2010d). Live births outside marriage: age of mother and type of registration, 1971 onwards (England and Wales): Population Trends. Available at www.statistics.gov.uk/StatBase/ssdataset.asp?vlnk=9557\&Pos=\&ColRank=1\&Rank=272

ONS (2011a). Mid-2009 Marital Status Estimates. Available at www.statistics.gov.uk/statbase/product.asp?vInk=15107

ONS (2011b). Marriages in England and Wales 2009: Statistical bulletin. Available at www.statistics.gov.uk/statbase/Product.asp?vlnk=14275

ONS (2011c). Marriage summary statistics 2009 (provisional). Available at www.statistics.gov.uk/statbase/Product.asp?vlnk=14275

ONS (2011d). Mid-2002 to Mid-2008 revised Marital Status Estimates (revised). Available at www.statistics.gov.uk/statbase/product.asp?vlnk=15107

ONS (2011e). Marriages. Available at www.statistics.gov.uk/cci/nugget.asp?id=322

ONS (2011f). Number of divorces, age at divorce and marital status before marriage. Available at www.statistics.gov.uk/statbase/Product.asp?vlnk=14124

ONS (2011g). Children of divorced couples. Available at www.statistics.gov.uk/StatBase/Product.asp? vlnk=14124\&Pos=3\&ColRank=1\&Rank=160 
ONS (2011h). Conceptions to women by age, year and quarter. Available at www.statistics.gov.uk/statbase/product.asp?vlnk=15055

Scottish Government (2010a). Table 1: Divorces and dissolutions granted, 2000-01 - 2009-10. Available at www.scotland.gov.uk/Publications/2010/12/17151409/3

Scottish Government (2010b). Abortions by place, age, deprivation, gestation, parity, repeat abortions and grounds for termination. Available at www.isdscotland.org/isd/1918.html 


\section{Notes}

${ }^{i}$ A household is a person living alone or a group of people who have the address as their only or main residence and who either share one meal a day or share the living accommodation.

ii A family is a married or cohabiting couple living together with or without children or a lone parent lining with his or her children. A family could also consist of grandparent(s) with their grandchild or grandchildren if the parent(s) are absent.

iii In general, a dependent child is a child aged under 16 (under 15 in earlier Census data) or one aged 16 to 18 in fulltime education who has never married and is living a family with their parent(s)

iv Civil partners have equal treatment to married couples in a number of legal matters such as tax, employment benefits, pension benefits, maintenance and recognition for immigration and nationality purposes.

${ }^{\vee}$ Conception estimates include pregnancies that result in one or more live births or stillbirths or which are terminated by a legal abortion. They do not include miscarriages or illegal abortions. 